\title{
ANALIZA GOSPODARKI-ŚWIATA WEDŁUG FERNANDA BRAUDELA
}

\author{
Tomasz Pawłuszko \\ Wydział Prawa, Administracji i Zarządzania \\ Uniwersytet Jana Kochanowskiego w Kielcach \\ ul. ul. Świętokrzyska 21, 25-406 Kielce \\ e-mail: tomaszpawluszko@ujk.edu.pl
}

\begin{abstract}
Streszczenie: Artykuł przedstawia zarys koncepcji światowego systemu gospodarczego w ujęciu Fernanda Braudela. Tematyka ta wiąże się z niemal równoległą teorią systemu-świata Immanuela Wallersteina, ale jest praktycznie nieznana w bieżącej literaturze. Autor zamierza zbadać kategorie pojęciowe i wątki teoretyczne francuskiego historyka pod kątem ich zastosowania we współczesnej analizie stosunków międzynarodowych. Koncepcja Braudela odwołuje się do teorii historii gospodarczej, teorii centrum-peryferie oraz studiów nad kapitalizmem i władzą polityczną. Wybór tego tematu jest powiązany z szerszymi pracami nad uwarunkowaniami pozycji regionu europejskiego w gospodarce światowej.
\end{abstract}

Słowa kluczowe: Fernand Braudel, system-świat, Immanuel Wallerstein, centra i peryferie, Annales

\section{WPROWADZENIE}

Celem tekstu jest analiza koncepcji gospodarki-świata autorstwa Fernanda Braudela. Jest to zagadnienie praktycznie nierozpoznane w kręgu badaczy stosunków międzynarodowych, którzy koncepcję tą kojarzą raczej z pracami Immanuela Wallersteina. Tymczasem to Braudel był pierwszym, który spopularyzował termin gospodarki-świata w powojennych naukach historycznych. Następnie Wallerstein wykorzystał go w swoich socjologicznych pracach poświęconych gospodarce kapitalistycznej. Pomysł zbadania tej kwestii wiąże się z kilkuletnimi studiami autora nad pozycjonowaniem państw w polityce i gospodarce światowej, zapoczątkowany jeszcze w okresie przygotowywania rozprawy doktorskiej.

Artykuł składa się z kilku części. Po pierwsze, przedstawiony zostanie zarys koncepcji F. Braudela, które zyskały spory posłuch wśród badaczy nauk społecznych. Po drugie, podkreślimy terminologię braudelowską. Po trzecie, zestawimy 
ją z kategoriami analizy systemu-świata (World-System Analysis, WSA) pióra I. Wallersteina ${ }^{1}$.

Na potrzeby artykułu przestudiowano kilka tysięcy stron prac poświęconych historii gospodarki europejskiej i światowej oraz metodologii jej badania. Kontekst $\mathrm{w}$ jakim się poruszamy to historia gospodarcza i międzynarodowa ekonomia polityczna. Interesujące nas prace opublikowano głównie w późnych latach 70 . XX wieku i do czasów dzisiejszych opatrzono je licznymi komentarzami, które także wymagały zbadania. Zwraca uwagę fakt, że zarówno wspomniany francuski historyk, jak i amerykański socjolog posiłkowali się dorobkiem polskiej szkoły historii gospodarczej. W tym miejscu dochodzi wątek lokalny. Jednym z węzłowych problemów analizy gospodarek regionalnych jest kwestia wielowiekowego zapóźnienia Europy Środkowo-Wschodniej (EŚW lub Central-Eastern Europe, CEE) i ekspansji kapitalizmu na różne tereny świata ${ }^{2}$. Problematyka ta była zwykle pomijana przez badaczy stosunków międzynarodowych, zajmujących się historią dyplomacji i instytucji politycznych. Tymczasem okazuje się, że przebogaty dorobek teoretyczny i faktograficzny powstały na bazie historii gospodarczej rzuca nowe światło na problemy rozwoju regionu EŚW w skali światowej. Każda analiza potęgi bierze swoje źródło w badaniu potencjału gospodarczego społeczeństwa. Kwestia była eksponowana w XX wieku zwłaszcza wśród badaczy o inspiracjach marksistowskich, ale i dziś budzi zainteresowanie naukowców z wielu dziedzin.

W pracy wykorzystano metodykę porównawczej analizy treści, badano kategorie i argumentację naukową oraz próby stworzenia modeli rozwoju społeczno-gospodarczego przez F. Braudela, I. Wallersteina i innych badaczy. Procesy te osadzono w kontekście rozwoju nauki o stosunkach międzynarodowych. W Polsce komentarze do prac Braudela i Wallersteina publikowali badacze, tacy jak W. Kula, M. Małowist, J. Topolski, J. Kochanowicz, czy A. Gałganek ${ }^{3}$. W XXI wieku zwracają uwagę prace A. Sosnowskiej, J. Swianiewicza, J. Czaputowicza, czy T. Klementewicza ${ }^{4}$.

1 Immanuel Wallerstein nie nazywał swego podejścia teorią, stąd konsekwentnie stosowany termin ,analiza”. Por. zbiór S.J. Babones, Ch. Chase-Dunn (red.) Routledge Handbook of WorldSystems Analysis, London \& New York 2012.

2 Por. J. Kochanowicz, Backwardness and Modernization. Poland and Eastern Europe in the 16th-20th Centuries. Burlington 2006; T. Zarycki (red.) Polska jako peryferie, Warszawa 2016.

3 W. Kula, Historia. Zacofanie. Rozwój, Warszawa 1983; M. Małowist, The Problem of the Inequality of Economic Development in Europe in the Latter Middle Ages, "Economic History Review", T. XIX (no. 1), 1966, s. 15-28; J. Topolski, Narodziny kapitalizmu w Europie XIV-XVII wieku, Poznań 2003, A. Gałganek, Zmiana w systemie międzynarodowym. Supercykle i wojna hegemoniczna, Poznań 1992.

4 A. Sosnowska, Zrozumieć zacofanie. Spory historyków o Europę Wschodnia 1947-1994, Warszawa 2004; J. Swianiewicz, Możliwość makrohistorii. Braudel. Wallerstein. Deleuze, Toruń -Warszawa 2014; J. Czaputowicz, Teorie stosunków międzynarodowych. Krytyka i systematyzacja. Warszawa 2006, s. 158-159; T. Klementewicz, Geopolityka trwałego rozwoju, Warszawa 2013. 
W badaniach nad stosunkami międzynarodowymi osoba F. Braudela jest zasadniczo nieobecna, względnie wskazuje się go, jako inspirację dla omawianych prac I. Wallersteina, choć zdarzają się wyjątki, takie jak prace T. Klementewi$\mathrm{cza}^{5}$. Podstawowe prace obu autorów są wydane w języku polskim. O samej zaś koncepcji systemu-świata w ujęciu Wallersteina pisali A. Aleksy, M. Rewizorski, czy G. Ziewiec ${ }^{6}$. Polski czytelnik ma do dyspozycji również tłumaczenie ważnej pracy B. Buzana i R. Little, którzy odwołują się do dorobku F. Braudela bardzo często, próbując ustalić nowe ramy badania historii stosunków międzynarodowych $^{7}$. Według badań ilościowych J. Czaputowicza, A. Wojciuk i K. Ławniczaka polscy badacze stosunków międzynarodowych praktycznie nie odwołują się do koncepcji F. Braudela, który kojarzony jest głównie z francuską szkołą stosunków międzynarodowych ${ }^{8}$. Zajmujemy się więc problematyką, która nie była dotąd szerzej opracowana w literaturze.

\section{GENEZA I ZNACZENIE KONCEPCJI FERNANDA BRAUDELA}

Sylwetka Fernanda Braudela znana jest w Polsce głównie historykom nowożytności, ale jego dorobek swobodnie przekracza granice dyscyplin nauki, takich jak historia i socjologia. Geneza koncepcji Braudela sięga lat przedwojennych, gdy był jeszcze nauczycielem w szkole średniej. Okresy letnie spędzał wówczas w archiwach Wenecji, Dubrownika, Madrytu, Paryża, Norymbergii, Augsburga, Lipska i innych miast, gdzie za pomocą kamery robił mikrofilmy tekstów źródłowych. Następnie w okresie 1935-1937 roku, które spędził na wykładach w Sao Paulo, czas wolny poświęcał na lekturę swoich mikrofilmów. Tak powstała opublikowana w 1949 roku dysertacja o historii Morza Śródziemnego, która zapoczątkowała błyskotliwą karierę naukową ${ }^{9}$ Także wtedy Braudel zastosował po raz pierwszy swój model „trzypiętrowej budowli” teoretycznej. Pisał używając trzech warstw narracyjnych: najpierw geografia regionu, potem gospodarka i społeczeństwo, a na koniec: polityka. W okresie późniejszym wskazywał, że wydarzenia polityczne stanowią najpłytszą część historii (I. Wallerstein pisał, że

5 T. Klementewicz, Teorie stosunków międzynarodowych $w$ strukturze wiedzy humanistycznej o systemie światowym (cywilizacji światowej), [w:] A. Gałganek, E. Haliżak, M. Pietraś (red.) Wieloi interdyscyplinarność nauki o stosunkach międzynarodowych, Warszawa 2012, s. 400-406.

6 A. Aleksy, Teoria systemu światowego Immanuela Wallersteina oraz jej znaczenie dla teorii stosunków międzynarodowych, [w:] R. Kuźniar (red.) Porządek międzynarodowy u progu XXI wieku. Warszawa 2005; M. Rewizorski, Koncepcja systemu światowego wedtug Immanuela Wallersteina, „Przegląd Politologiczny”, nr 1, 2009, s. 65-78; G. Ziewiec, Wallersteina i Fukuyamy prognozy systemu kapitalistycznego, „Gospodarka Narodowa”, Nr 1-2, 2009, s. 27-47.

7 B. Buzan, R. Little, Systemy międzynarodowe w historii świata, Warszawa 2011.

8 J. Czaputowicz, K. Ławniczak, A. Wojciuk, Nauka o stosunkach międzynarodowych i studia europejskie $w$ Polsce, Warszawa 2015, s. 26.

9 J. Kochanowicz, Twórca i dzieło, [w:] F. Braudel, Kultura materialna, gospodarka i kapitalizm XV-XVIII wiek, t. 1, Warszawa 1992, s. 5-7. 
Braudel nazywał je „kurzem”"10). Widać tu wpływy Paula Lacombe, który w 1894 roku spopularyzował pojęcie „historii wydarzeniowej”"1. Wydarzenia polityczne są bowiem jednorazowe i wynikają z głębszych zmian gospodarczych (rytm, koniunktura) i ewolucji struktur społecznych, które są najstabilniejsze i nadają się do badania w długiej perspektywie, czyli tzw. długim trwaniu. Braudel korzystał zatem aż z trzech rejestrów czasowych na raz.

Podejście to było nowością, ponieważ uczyniło bohaterami historii już nie władców i wodzów, ale tzw. zwykłych ludzi ${ }^{12}$. Jak dowodził, ludzie na różnych krańcach Morza Śródziemnego mieli podobne rodziny, podobnie umierali, tak samo pracowali i tak samo udoskonalali swe życie. Francuski historyk w analizie brał pod uwagę styl życia, ubiór, budowę domów, handel, zmiany cen, a nawet malarstwo. Pomysł napisania takiej pracy podsunął Braudelowi jego mistrz Lucien Febrve. Jednocześnie Braudel pozostawał wierny inspiracji Marca Blocha, który wskazywał, że historia powinna badać zmiany jakościowe ${ }^{13}$. Dążył do integracji nauk o człowieku, czym zyskał sympatię wielu uczonych. Z jego inspiracji korzystali $\mathrm{m}$. in. Michel Foucault oraz Immanuel Wallerstein, o czym poniżej. $\mathrm{W}$ podobnie interdyscyplinarnym duchu pisali o znaczeniu historii nobliści z dziedziny ekonomii: John Hicks i Douglass North ${ }^{14}$.

W 1929 roku młodzi historycy Lucien Febvre i Marc Bloch założyli czasopismo Annales d'Histoire Economique et Sociale (warto zauważyć, że i równolegle w Polsce w 1931 roku z inicjatywy F. Bujaka i J. Rutkowskiego powstało czasopismo Roczniki Dziejów Społecznych i Gospodarczych) ${ }^{15}$. Po dramatycznej śmierci M. Blocha w 1944 roku współredaktorem Annales został Fernand Braudel. W 1947 roku we francuskim Ecole Pratique des Hautes Etudes powstała VI sekcja poświęcona naukom ekonomicznym i społecznym, którą kierował do 1956 roku Lucien Febvre. Kilka lat po objęciu stanowiska po Blochu, bo w 1950 roku został profesorem College de France w katedrze historii nowożytnej. Po śmierci Febrve'a w 1956 roku przejął Braudel zarówno redakcję Annales, jak i kierownictwo VI sekcji, która przekształciła się w samodzielną placówkę naukową. Braudel kierował nią aż do przejścia na emeryturę w 1977 roku. Ponadto, równolegle zarządzał powstałą w 1963 roku fundacją Maison des Sciences de l'Homme, mającą na celu integrację nauk społecznych pod egidą historii. Projekt ten sponsorowała fundacja Forda i fundusze rządowe. Fundacja zgromadziła świetną bibliotekę. Jak

${ }^{10}$ I. Wallerstein, Analiza gospodarki-świata. Wprowadzenie, Warszawa 2007, s. 31.

${ }_{11}$ Przywołuję za J. Swianiewicz, Możliwość makrohistorii..., s. 152-153.

12 Jak pisał w przedmowie do zbioru esejów Braudela znający go osobiście W. Kula i B. Geremek w Rzymie na X Kongresie Nauk Historycznych niemiecki historyk Gerhard Ritter zaatakował Braudela za zajmowanie się ludźmi, którzy „nie mają historii”. W. Kula, B. Geremek, Przedmowa, [w:] F. Braudel, Historia i trwanie, Warszawa 1999, s. 6-8.

${ }_{13}$ M. Bloch, Pochwała historii, czyli o zawodzie historyka, Kęty 2009, s. 37-94.

${ }_{14}$ J. Hicks, Teoria historii gospodarczej, Torun 2000; D. North, Zrozumieć przemiany gospodarcze, Warszawa 2014.

15 W. Kula, Przedmowa, [w:] M. Bloch, Pochwata historii..., s. 15-28. 
wspominał Jacek Kochanowicz, Braudel był świetnym organizatorem i starał się zapraszać do Ecole badaczy z różnych dziedzin nauk społecznych, a pozostawanie poza sztywną strukturą francuskich uniwersytetów dało mu swobodę ${ }^{16}$. Szkoła prowadziła badania interdyscyplinarne i stosowała również narzędzie ilościowe. Po odwilży 1956 roku do zespołu zaczął zapraszać również uczonych z tzw. bloku wschodniego, głównie z Polski i Węgier. W 1956 roku pod auspicjami UNESCO odbyła się polsko-francuskie seminarium historyczne ${ }^{17}$. Współpracę z zespołem Braudela podejmowali Witold Kula, Jerzy Topolski, Andrzej Wyczański, Marian Małowist i inni. Sam Braudel również podróżował do państw Europy Wschodniej, Bronisław Geremek wskazywał w jego pracach obecność źródeł z archiwów Gdańska, Krakowa i Warszawy ${ }^{18}$. W badaniach stale propagował łączenie różnych nauk i teorii oraz krytykował tradycjonalizm, skupiony na historii politycznej.

Za najpopularniejsze dzieło Braudela uważa się wspomnianą książkę o Morzu Środziemnym. W tym szkicu zajmiemy się jego późniejszymi pracami. Kluczowa jest zwłaszcza ogromna, trzytomowa praca zatytułowana Kultura materialna, gospodarka i kapitalizm w XV-XVIII wieku. Pierwszy tom z podtytułem Struktury codzienności ukazał się w 1967 roku, kolejne dwa - Gry wymiany i Czas świata - w 1979 roku, już po publikacji pierwszego tomu pracy Modern World-System pióra Immanuela Wallersteina, z którego terminologii Braudel ochoczo skorzysta $^{19}$. Obaj badacze nieodmiennie darzyli się estymą i pochlebnie wypowiadali się o swoich pracach. Po opublikowaniu Kultury materialnej... Braudel miał lat 77. Książkę tą wydano szybko w Argentynie, Chile, Grecji, Hiszpanii, Japonii, Meksyku, Polsce, Portugalii, RFN, Rumunii, Szwecji, USA, UK, Węgrzech, Włoszech i w ZSRR. Do swej śmierci w 1985 roku Braudel uzyskał doktoraty honoris causa 11 uniwersytetów (w tym Uniwersytetu Warszawskiego) i członkostwo 11 akademii nauk (w tym Polskiej Akademii Nauk).

Credo swojej wizji badań humanistyczno-społecznych zawarł Braudel w wykładach i tekstach z okresu 1950-1960, opublikowanych również w wielu językach pod nazwą Historia i trwanie (pierwszy przekład polski ukazał się w 1971 roku ${ }^{20}$. Swój wykład inauguracyjny w College de France w 1950 roku zatytułował z patosem „Odnowa historii” ${ }^{21}$. Wskazywał w nim na zmienność metodologii nauk humanistycznych i społecznych. Doświadczenia wojen światowych pchały naukowców do zadawania rozlicznych przyczyn o kondycję człowieka i nauki.

${ }^{16}$ J. Kochanowicz, Twórca i dzieło, [w:] F. Braudel, Kultura materialna..., s. 5-7.

17 W. Kula, Uwagi o aktualnych tendencjach $w$ badaniu historii gospodarczo-społecznej, [w:] tenże, Historia..., s. 210-226. M. Pasztor, Francja wobec października 1956 r. w Polsce, [w:] J. Rowiński (red.) Polski październik 1956 w polityce światowej, Warszawa 2006, s. 274-276. W seminarium wzięło udział 30 polskich intelektualistów.

${ }^{18}$ W. Kula, B. Geremek, Przedmowa..., s. 9.

19 I. Wallerstein, The Modern World-System: Capitalist Agriculture and the Origins of the European World-Economy in the Sixteenth Century, New York 1974.

${ }^{20}$ F. Braudel, Historia i trwanie, Warszawa 1999.

${ }^{21}$ F. Braudel, Odnowa historii, [w:] Historia i trwanie..., s. 21-42. 
Braudel był przekonany, że nie tylko ludzie tworzą historię, ale też, że historia tworzy ludzi. Protestował przeciw historii politycznej, gdyż opisywała jedynie działania jednostek, co czyniło z niej dehumanizującą ideologię i iluzję. Uważał, że dużo ważniejsze są szersze procesy. Na przykład koniunktura gospodarcza, która steruje masowymi zmianami społecznymi w skali międzynarodowej. W wykładzie podał przykład badania kryzysu we Florencji po roku 1580. Przyczyny kryzysu wiodły jego zdaniem poprzez handel portugalski i arabski, aż po Indie i Chiny oraz ich potrzeby surowcowe. Pisał też o historii flot morskich oraz znaczeniu wizerunku śmierci w sztuce, rozumianej jako zapowiedź racjonalizmu. Według francuskiego historyka historia ma „tysiąc prędkości” na raz, a zadaniem badacza społecznego jest badanie tego, co w sposób jakościowy tworzy dane społeczeństwo, które agreguje te wszystkie historie w jedną opowieść. Są to w jego opinii procesy trwałe, nie efemeryczne. Podejście takie wyznacza historii zadanie integracji rozproszonych nauk o człowieku.

Podejście takie wymaga syntezy wielu nauk, o którą apelował w eseju $O$ ekonomię historyczna, również z 1950 roku $^{22}$. Jako przykład podawał zastosowanie przez historyków metod pracy ekonomistów: badań cykli, cen i koniunktur. Próbę własnej syntezy wyłożył w eseju Historia i nauki społeczne: dlugie trwanie, który ukazał się na łamach Annales w 1958 roku. Wskazywał w nim, że nauki podzielone na wąskie specjalizacje tworzą bariery hamujące refleksję o człowieku i społeczeństwie. Imponowało mu podejście amerykańskie, które pragmatycznie łączyło różne dziedziny studiów w ramach specjalistycznych area studies, badających całe kontynenty i cywilizacje. Historia dzięki wiedzy z zakresu ekonomii, etnografii, psychologii, socjologii, demografii, statystyki, może uzyskać nowe spojrzenie na rzeczywistość. Aby jednak ująć całość zmian, należy odejść od tzw. historii wydarzeniowej (kapryśnym i mylącym „krótkim trwaniu”, który lepiej nadaje się dla dziennikarza, nie dla naukowca) i zagłębić się w tytułową historią długiego trwania, która w dużej mierze jest historią nieświadomą. Ludzie tworzą bowiem historie, ale nie tworzą jej świadomie ${ }^{23}$.

Drugą ważną inspiracją oprócz łączenia obszarów badawczych różnych nauk było łączenie ich metod. Był to okres tzw. rewolucji behawioralnej w naukach społecznych ${ }^{24}$. Pojawily się nowe sposoby narracji i nowe metodyki zbierania danych i wyjaśniania. Naukowcy zaczęli badać systemy, cykle, trendy, koniunktury zmian społecznych i ekonomicznych. Zjawisko to pchnęło Braudela do zastosowania koncepcji struktury, która organizuje stosunek społeczeństwa do rzeczywistości i pozwala dostrzegać nowe fakty, problemy badawcze i próby ich wyjaśnienia. $\mathrm{W}$ tej perspektywie ważne jest dostrzeganie teorii i modeli zjawisk i procesów społecznych w kilku perspektywach czasowych i przestrzennych. W podsumowa-

${ }^{22}$ F. Braudel, O ekonomię historyczna, [w:] tenże, Historia ..., s. 115-125.

${ }^{23}$ F. Braudel, Historia i nauki społeczne: dhugie trwanie, [w:] tenże, Historia ..., s. 47-86.

${ }^{24}$ Popularność w naukach społecznych zyskały funkcjonalistyczne koncepcje systemowe m.in. T. Parsonsa, D. Eastona, M. Kaplana i innych. 
niu Francuz mówił o trzech liniach zbiorowych badań nauk społecznych: matematyzacji, redukcji do przestrzeni i długim trwaniu ${ }^{25}$. Sam starał się konsekwentnie prezentować to stanowisko w swoich pracach.

Pewną słabością $\mathrm{w}$ analizie nauk historycznych i społecznych (w tym politologii) jest używanie języka literackiego i niekiedy potocznego ${ }^{26}$. Stąd i finalny postulat Braudela, aby tworzyć interdyscyplinarny język nauki, oparty na modelach. Całość wizji środowiska Annales konsultowana była też z polskimi badaczami, między innymi Witoldem Kulą i Aleksandrem Gieysztorem. Braudel pisał, iż „Nasi polscy koledzy określają te zgrane ruchy całościowe dogodnym mianem badań kompleksowych"27. Gieysztor wskazywał, że prace różnych specjalistów nad jednym tematem mogłyby być ograniczane de facto tylko przez jedną, dwie lub trzy zasady klasyfikacji zjawisk społecznych: geograficzną, chronologiczną lub wedle istoty samego przedmiotu. Wówczas uzyskiwano podejście podobne do wspomnianych amerykańskich area studies. Tuż przed publikacją pierwszego tomu Kultury materialnej... Braudel przyjął, że poziomy analizy historycznej są trzy: mikrohistoria, historia koniunkturalna, historia strukturalna. Nazwy odpowiadały zmianom języka nauki okresu behawioralizmu, ale bazę dla tego ujęcia stworzył Braudel już kilkadziesiąt lat wcześniej, publikując Morze Śródziemnee ${ }^{28}$.

\section{PODSTAWOWE KATEGORIE TEORETYCZNE}

Trylogia Kultura materialna, gospodarka i kapitalizm liczy ponad półtora tysiąca stron. Jej konstrukcja zasadza się na trójpodziale wskazanym w tytule. W tomie pierwszym Braudel omawia problematykę rozwoju kultury materialnej w okresie XV-XVIII wieku, w tomie drugim pojawia się „drugie piętro” analizy, czyli gospodarka. Tom trzeci poświęcony jest kapitalizmowi, który francuski historyk uważał za „ostatnie piętro” gospodarki rynkowej ${ }^{29}$.

W tomie poświęconym kulturze materialnej analizowane są podstawowe długofalowe trendy zmieniających się społeczeństw nowożytnych. Braudel omawia kwestię demografii, żywności, zaopatrzenia w wodę, osobne rozdziały zyskały kwestie projektowania domostw, dostarczania energii, zagadnień rewolucji przemysłowej, pieniądza i miast. Autor omawia szczegóły zmian w długim trwaniu, nie skupia się na biografiach, ani pojedynczych wydarzeniach. Jeśli się one pojawia-

${ }^{25}$ F. Braudel, Historia i nauki spoleczne..., s. 86.

${ }^{26}$ Por. poruszająca ten temat praca R. Skarzyński, Podstawowy dylemat politologii, Białystok 2012.

${ }^{27}$ F. Braudel, Jedność i różnorodność nauk o człowieku, [w:] tenże, Historia i trwanie..., op cit, s. 96-100.

${ }^{28}$ F. Braudel, Morze Śródziemne i świat sródziemnomorski w epoce Filipa II, t. 1-2, Gdańsk 1976-1977.

${ }^{29}$ F. Braudel, Kultura materialna, gospodarka i kapitalizm XV-XVII wiek, t. 1-3, Warszawa 1992. 
ją, to tylko dlatego, żeby wytłumaczyć przypadki określonych zmian społeczno-gospodarczych. Kwestii politycznych prawie w ogóle nie ma, za to z pietyzmem Braudel omawia detale życia codziennego na kilku kontynentach. Dowiadujemy się, co ludzie jedzą, gdzie mieszkają, dlaczego i kiedy głodują, co produkują, czym handlują i jak się przemieszczają. Detalizm tego ujęcia jest nieoceniony, choć do rozwlekłego stylu pisania autora trzeba się przyzwyczaić. Książka powstawała $\mathrm{z}$ inspiracji L. Febrve w okresie około piętnastu lat (1952-1967) ${ }^{30}$.

Tom drugi powstawał w trakcie wykładów Braudela w College de France w ciągu kilkunastu lat. We wstępie doń autor przedstawia zarys swojej koncepcji. Jak wspomnieliśmy, jest to trzypiętrowa „,budowla”: podstawą jest życie materialne, piętro nad nim życie gospodarcze (wymiana, pieniądz, giełda, jarmark). Jego zdaniem gospodarka zaczyna się tam, gdzie pojawia się wartość wymienna. Wymiana jest interakcją - procesem, który zachodzi między producentami a konsumentami. Celem tomu jest ogólna historia gospodarcza lub jej model, choć Braudel przyznaje, że ów model nie nadaje się do ścisłej weryfikacji w formie matematycznej ${ }^{31}$. Był to model ,jakościowy” w sensie Marca Blocha. Chodzi zatem o rozpoznanie form i procesów rozwojowych, uzyskanych dzięki analizie porównawczej (badana jest wymiana gospodarcza na kilku kontynentach). Ostatnim ,piętrem” analizy jest kapitalizm rozumiany dosyć specyficznie, jako akumulacja władzy (wymiana oparta na stosunku sił i potrzeb) i swoiste ,pasożytnictwo społeczne"32. To najwyższe piętro, wybudowane najpóźniej, bo funkcjonująca w tzw. pułapce maltuzjańskiej gospodarka przez całe stulecia opierała się poniżej progu wymiany.

Tom trzeci obrazuje braudelowską wizję rozwoju gospodarki nowożytnej jako całości. We wstępie przyznaje, że inspiracje zbierał z przedwojennych jeszcze książek Józefa Kuliszera (powszechna historia gospodarcza) i Wernera Sombarta (historia kapitalizmu) ${ }^{33}$. Dodaje też, że najlepsi badawcze nie oddzielają ekonomii od reszty spraw społecznych, ale poszerzają jej rozumienie o inne sfery, tak jak J. Schumpeter, czy K. Polanyi ${ }^{34}$. Jedna dyscyplina nauki jest tylko jednym punktem widzenia. Podobnie wypowiadać się będzie o swoich inspiracjach i wizjach nauki Immanuel Wallerstein, który pobyt seminarium Braudela w latach 60. XX wieku wykorzystał do stworzenia własnych koncepcji „systemu-świata” i „historycznych nauk społecznych".

${ }^{30}$ Początkowo praca miała być wspólnym przedsięwzięciem obu historyków, ale śmierć Febrve'a w 1956 roku przekreśliła te plany. Braudel zdecydował się kontynuować pracę samodzielnie.

${ }^{31}$ F. Braudel, Kultura materialna ..., t. 2, s. 5-9.

32 Ibidem, s. 8.

${ }_{33}$ J. Kuliszer, Powszechna historia gospodarcza średniowiecza i czasów nowożytnych, Warszawa 1961; W. Sombart, Der Moderne Kapitalismus, wyd. 15, Berlin 1928, za: F. Braudel, Kultura materialna ..., t. 2, s. 562.

${ }^{34}$ J. Schumpeter, Kapitalizm, socjalizm, demokracja, Warszawa 1995; J. Schumpeter, History of Economic Analysis, London 1954; K. Polanyi, Wielka transformacja. Polityczne i ekonomiczne źródła naszych czasów, Warszawa 2010. 
Tak jak w tomie drugim pojawiła się definicja kapitalizmu, tak w tomie trzecim Braudel zajmuje się terminem gospodarki-świata i reguł nią rządzących. Omówimy obie kategorie, ponieważ ich rozumienie rzuca światło na stanowisko Braudela w debacie naukowej.

Zdaniem francuskiego historyka zjawisko kapitalizmu pojawiło się stosunkowo późno. Słowo „kapitał” było oczywiście wcześniejsze od dzisiaj rozumianego kapitalizmu, którego pojęcie ukształtowało się dopiero na progu XX wieku. W drugim tomie Kultury materialnej... Braudel thumaczy, że w sumie mógłby ominąć pojęcie kapitalizmu, ponieważ w długiej perspektywie istniało wiele pojęć alternatywnych. W przeciwieństwie do wielu badaczy Francuz uważał, że kapitalizm jest tylko niewielką częścią życia gospodarczego i stanowi obszar inwestycji i wysokiej wydajności kapitału. Samo słowo capitale pochodzi z łaciny ludowej, a źródłosłów stanowi wyraz „głowa” (,caput”). Od XII-XIV wieku termin ten pojawia się w znaczeniu funduszy, bądź majątku i nie jest precyzyjnie definiowany. Występuje na określenie bogactwa, rozumianego jako kapitał pieniężny ${ }^{35}$. Do XVIII wieku popularniejsze będzie słowo „fundusze”, a także zasoby, pieniądze, dobra, gotówka, mienie, majątek oraz bogactwo, które jest popularnym i opisowym określeniem zamożności. Słowo „kapitalista” pojawia się natomiast w połowie XVII wieku, oznacza ludzi zamożnych, w encyklopediach francuskich pojawia się także przymiotnik „kapitalistyczny”. W wieku XVIII nadal niemal zawsze chodzi o właścicieli fortun i kosmopolitów. Braudel zauważa, że słowo „kapitał” dopiero u Karola Marksa zaczyna oznaczać środek produkcji. Od Marksa też Braudel przejmie pojęcia kapitału stałego i zmiennego, które nazwie trwałym i obrotowym. Słowo „kapitalizm” jest jeszcze późniejsze. Według encyklopedii francuskiej z 1753 roku „kapitalizm” to „stan tego, który jest człowiekiem bogaty”. Co ciekawe, w słowniku z 1932 roku „kapitalizm” oznacza po prostu „,ogół kapitalistów”, a jeszcze w 1958 - „,system gospodarczy, w którym dobra produkcji należą do osób prywatnych lub prywatnych spółek"36. Mistrz Braudela, Lucien Febrve chciał słowo „kapitalizm” wręcz wyeliminować $z$ dyskursu naukowego, uważając je za zużyte i niejasne. Na podstawie tych badań pojęciowych Braudel uważał, że termin „kapitalizm” nie był używany przez historyków gospodarki nowożytnej, bo kapitalizm dawny zajmował raczej wąską płaszczyznę życia w długim trwaniu i dotyczył bardzo drobnej grupy przedsiębiorców, którzy prowadzili działalność kupiecką na poziomie międzynarodowym.

Jest to ujęcie zasadniczo inne, niż większości dwudziestowiecznych badaczy. W interesującym przekrojowym studium F. Ilkowski rekonstruuje poglądy wielu myślicieli na temat imperializmu kapitalistycznego. Poczynając od Hannah Arendt i Raymonda Arona, zwraca uwagę na m. in. nawiązujące do marksizmu prace Andre Gunder Franka, Arghiri Emmanuela, Samira Amina, Giovanniego

${ }^{35}$ F. Braudel, Kultura materialna ..., t. 2, s. 207-217.

${ }^{36}$ Ibidem, s. 215-218. 
Arrighi ${ }^{37}$. Autorzy ci związani będą przez lata ze szkołą I. Wallersteina, choć ich zainteresowania będą ewoluować po zakończeniu zimnej wojny. Również Geoffrey Ingham prezentujący zagadnienie genezy kapitalizmu w dyskursie naukowym zajmuje się raczej Maxem Weberem, Josephem Schumpeterem i Johnem Keynesem, a wspomina Fernanda Braudela wprost tylko dwukrotnie: gdy pisze o tym, że wywodzący się z kupiectwa kapitalizm dąży do monopolu i gdy komentuje zachowanie kapitalistów jako dążących do bogactwa „drapieżców” kontrolujących przepływ pieniądza dzięki sieciom wymiany i rynkom ${ }^{38}$. Braudel odróżniał rynek od kapitalizmu, dziś te terminy bywają używane zamiennie.

Francuski historyk korzystał twórczo z prac Witolda Kuli i Jerzego Topolskiego, aby na przykładzie zachowań ekonomicznych polskiej szlachty pokazać, że istnieje inna racjonalność działań rynkowych niż kapitalistyczna ${ }^{39}$. Zdaniem polskich badaczy większość zachowań ekonomicznych w Europie Wschodniej aż do końca XVIII wieku będzie miała raczej proweniencję feudalną. Inną drogą poszedł Immanuel Wallerstein, który cytując najczęściej F. Braudela i M. Małowista - w sprawie znaczenia i rozpowszechnienia się kapitalizmu poprzez handel przyznał rację raczej Polakowi ${ }^{40}$. Wątek ten prowadzi nas do kolejnego rozróżnienia.

Termin gospodarka-świat nie został wymyślony przez Immanuela Wallersteina, choć to on rozpropagował to określenie. Pochodzi ono od określenia Weltwirtschaft z pracy niemieckiego historyka Fritza Röriga z 1933 roku, które do obiegu wprowadził Braudel pod koniec lat 40. XX wieku pod nazwą économie-monde $e^{41}$. Braudel był zdania, że gospodarka światowa (économie mondiale) jest czymś innym, niż gospodarka-świat. Ta pierwsza obejmuje „rynek całego świata”, ta druga to fragment świata, kawałek planety samodzielny gospodarczo, „w zasadzie samowystarczalny i odznaczający się, dzięki swym wewnętrznym powiązaniom i wymianie, pewną organiczną jednością" ${ }^{2}$. Jego zdaniem gospodarki-światy istniały zawsze. Ostatnia uwaga posłużyła politologom B. Buzanowi, R Little i F. Fukuyamie tworzyć wizje wspólnot gospodarczych i politycznych sięgających kilku tysięcy lat ${ }^{43}$. W Polsce podobny pogląd zaprezentowali niedawno w swoich książkach A. Gałganek i T. Klementewicz ${ }^{44}$.

${ }^{37}$ F. Ilkowski, Imperializm kapitalistyczny we współczesnych ujęciach teoretycznych, Toruń 2015.

${ }^{38}$ G. Ingham, Kapitalizm, Warszawa 2009, s. 130 i 200.

${ }^{39}$ W. Kula, Teoria ekonomiczna ustroju feudalnego, II wyd., Warszawa 1983, W. Kula, Rozwój gospodarczy Polski XVI-XVIII w., Warszawa 1993; J. Topolski, Narodziny kapitalizmu...

${ }^{40}$ Por. M. Małowist, Wschód a Zachód Europy w XIII-XVI wieku. Konfrontacja struktur spoteczno-gospodarczych. Warszawa 2006.

${ }^{41}$ F. Braudel, Kultura materialna ..., t. 3, s. 11-13.

${ }^{42}$ Ibidem., s. 11-15.

${ }^{43}$ B. Buzan, R. Little, Systemy międzynarodowe..., F. Fukuyama, Historia ładu politycznego, Od czasów przedludzkich do rewolucji francuskiej, Poznań 2012.

${ }^{44}$ A. Gałganek, Historia stosunków międzynarodowych. Nierówny i połaczony rozwój, t. 1-2, Warszawa 2013; T. Klementewicz, Geopolityka trwatego rozwoju..., T. Klementewicz, Stawka większa niż rynek. U źródeł kapitalizmu bez granic, Warszawa 2015. 
Według modelu Braudela cechami gospodarki-świata jest (1) posiadanie ograniczonej przestrzeni, (2) dominującego miasta oraz (3) hierarchii stref rozwoju gospodarczego: centrum, półperyferii i peryferii ${ }^{45}$. Tutaj mamy do czynienia z wyrażoną wprost inspiracją pracami Wallersteina, który z kolei korzystał z prac Raula Prebischa i teorii dependystów ${ }^{46}$. Według Braudela w epoce nowożytnej hierarchia stref gospodarczych była następująca: miasto-prowincja-kolonia. Strefy te cechują się współzależnością i zmiennością. Ponadto gospodarki-światy charakteryzują się występowaniem stref neutralnych, takich jak ubogie obszary wokół stolic, czym odpierał zarzut politologów, iż nawet w państwach centrum istnieją znaczące obszary biedy ${ }^{47}$. Braudel był skądinąd sceptyczny wobec instytucji państwa. Pokazując wielowiekowe procesy krążenia ludzi, towarów i idei przez całe kontynenty zwracał uwagę na jego marginalną rolę. Bardziej interesowały go aktywności i interesy poszczególnych grup/klas społecznych, takich jak szlachta, mieszczaństwo, rzemieślnicy, przedsiębiorcy, kupcy i chłopi, którzy współtworzyli wymianę i krążenie technologii, produktów, stylów życia i in. Jak wiemy, historia polityczna i wojskowa stanowi dla Braudela margines zainteresowań. Działania dynastii oraz przedsięwzięcia militarne stanowiły znikomą część życia materialnego wielomilionowych populacji gospodarek-światów, choć naturalnie miały znaczenie w ich określaniu. Prymat gospodarki nad polityką ma u Braudela zdecydowanie korzenie marksowskie. Schemat uogólniający relacje między tymi obszarami jest u niego następujący: życie materialne/gospodarcze tworzy społeczeństwo, które jest „zbiorem zbiorów” społecznych, a które na powierzchni tworzy instytucje polityczne do bieżącego zarządzania. W praktyce w epoce nowożytnej władcy nie mieli większego wpływu na mieszczaństwo, uczelnie, duchowieństwo, szlachtę, czy handel. Nawet scentralizowane monarchie absolutne posiadały jedynie nieliczną administrację, dyplomatów i wojsko (zwykle zaciężne, nie obywatelskie). Dlatego zamiast o polityce, która koncentruje się na kwestiach ulotnych (,zdarzeniowych”), wolał Braudel pisać o „hierarchiach społecznych". W tym ujęciu zauważalne jest przywiązanie Braudela do koncepcji społecznego tworzenia rzeczywistości ${ }^{48}$. Era masowych ruchów społecznych, demokratyzacji, edukacji, urbanizacji, industrializacji oraz masowego wojska nadeszła dopiero w XIX wieku, po uzyskaniu dominacji przez idee liberalne ${ }^{49}$.

${ }^{45}$ F. Braudel, Kultura materialna..., t. 3, s. 15-35.

46 I. Wallerstein, The Modern World-System..., R. Prebisch, Commercial Policy in the Underdeveloped Countries, "American Sociological Review” 1959, vol. 49, no. 2, s. 251-273; A.G. Frank, Immanuel and Me With-Out Hyphen, "Journal of World-Systems Research", vol. 6, no. 2, summer/fall, 2000, s. 216-231. J. Hryniewicz, Teoria centrum-peryferie w epoce globalizacji, „Studia Regionalne i Lokalne”, nr 2 (40) 2010 s. 5-27; J. Hryniewicz, Centrum-Peryferie. Stara teoria w nowych czasach, „Studia Polityczne”, nr 31. 2013, s. 291-313.

${ }^{47}$ F. Braudel, Kultura materialna ..., t. 3, s. 30-33.

48 Por. P. Berger, T. Luckmann, Społeczne tworzenie rzeczywistości, Warszawa 1983.

49 Por. I. Wallerstein, Unthinking Social Science: The Limits of Nineteenth Century Paradigms, Cambridge 1991. 


\section{FERNAND BRAUDEL A IMMANUEL WALLERSTEIN}

Immanuel Wallerstein jako znany afrykanista brał udział w seminariach Fernanda Braudela we Francji. Udział w nich stał się jedną z podstawowych inspiracji dla jego koncepcji, które wyłożył w artykule w 1974 roku, a następnie w pierwszym tomie The Modern World-System ${ }^{50}$. Książka ta ukazywała tworzenie się kapitalistycznej gospodarki światowej w XVI wieku z centrum w Europie. Odwoływał się tym samym do koncepcji „długiego wieku szesnastego”, autorstwa Braudela. Wallerstein przyjął za Marianem Małowistem, że stworzenie systemu globalnej wymiany handlowej według zasad kapitalistycznych stworzyło pierwszy w historii globalny system gospodarczy, który nazwał gospodarką-światem. Kolejne tomy tego dzieła, przedstawiającego socjologiczne ujęcie rozwoju gospodarki -świata, ukazały się w 1980 roku (okres 1600-1750), 1989 (okres 1730-1840) oraz w 2011 roku (do 1914 roku). Mimo przekroczenia w 2010 roku wieku 80 lat Wallerstein zapowiedział jeszcze dwa tomy The Modern World-System, które mają sięgać perspektywą do 2050 roku. Oprócz tych książek udoskonalał Wallerstein swoją metodykę publikując między innymi The Capitalist World-Economy (1979), World-Systems Analysis: Theory and Methodology (1982), Historical Capitalism (1983), The Politics of the World-Economy (1984), Geopolitics and Geoculture (1991), Unthinking Social Science (1991), After liberalism (1995), czy The End of the World As We Know It (1999) ${ }^{51}$. W 2004 roku opublikował skrótowe wprowadzenie do własnego dorobku: World Systems Analysis: An Introduction. Dwie ostatnie pozycje zostały przetłumaczone na język polski ${ }^{52}$.

Fernand Braudel zdołał zapoznać się z pierwszym tomem The Modern World -System oraz z maszynopisem części drugiej, nim opublikował ostatnie dwa tomy Kultury materialnej... Wallerstein bardzo szybko przeszczepił na grunt amerykański idee integracji nauk o człowieku oraz koncepcje systemowe Braudela. Po kilkunastu latach pracy w Columbia University (1958-1971) i kilku w McGill University (1971-1976) w 1976 roku w ramach nowojorskiego uniwersytetu stanowego w Binghamton otworzył Fernand Braudel Center for the Study of Economies, Historical Systems and Civilization (i pozostał jego dyrektorem aż do emerytury w 1999 roku, by następnie związać się z Yale University) ${ }^{53}$.

${ }^{50}$ I. Wallerstein, The Rise and Future Demise of the World Capitalist System: Concepts for Comparative Analysis, "Comparative Studies in Society and History", no. 16, 1974, s. 387-415.

${ }^{51}$ I. Wallerstein, The Capitalist World-Economy, Cambridge 1979; T.K. Hopkins, I. Wallerstein et al., World-Systems Analysis: Theory and Methodology, Sage - Beverly Hills 1982; I. Wallerstein, Historical Capitalism, London 1983; tenże, Politics of the World-Economy, Cambridge 1984; tenże, Geopolitics and Geoculture, Cambridge 1991; tenże, Unthinking...; tenże, After Liberalism, New York 1995.

${ }_{52}$ I. Wallerstein, Koniec świata jaki znamy, Warszawa 2004; I. Wallerstein, Analiza systemów-światów. Wprowadzenie, Warszawa 2007.

${ }^{53}$ Por. W. Goldfrank, Paradygmat odzyskany? System-świat I. Wallersteina i jego analiza, dostępny on-line: http://www.turowski.uni.wroc.pl/paradygmat.htm (26.03.2017). 
Żyjący wciąż Braudel zgodził się na firmowanie swoim nazwiskiem nowego instytutu Wallersteina, obu łączyła nadzieja na globalny rozwój makro-analiz zmian społecznych. Nowej instytucji towarzyszył kwartalnik Review, A Journal of the Fernand Braudel Center oraz uruchomiony w 1995 roku półrocznik Journal of World-Systems Research. Wkrótce powstał też kolejny instytut Institute for Research on World-Systems, ulokowany na uniwersytecie kalifornijskim w Riverside. Oba instytuty i czasopisma istnieją do dzisiaj. Wallerstein zyskał dużą popularność jako lewicowy teoretyk i komentator życia politycznego oraz przewodniczący Międzynarodowego Towarzystwa Socjologicznego (1994-1998) i szef Komisji Gulbenkiana, której celem było opracowanie kierunków rozwoju nauk społecznych na kolejne 50 lat (1994-1995).

W polskiej debacie najbardziej wnikliwe porównania stanowisk F. Braudela i I. Wallersteina przygotowali wspomniani Anna Sosnowska oraz Jan Swianiewicz. O ile A. Sosnowska zwróciła uwagę na różnice w pojmowaniu kapitalizmu u obu autorów, o tyle J. Swianiewicz zauważył, że Wallerstein szybko spłacił intelektualny dług, jaki zawdzięczał inspiracji F. Braudela. Jak zwróciliśmy powyżej uwagę, pierwszy tom Kultury materialnej, wspaniały pod względem zawartej faktografii, nie tworzył zwartego modelu uprawiania nauk historycznych. Metodykę i próbę modelu zawarł Francuz dopiero w tomach drugim i trzecim, korzystając z siatki pojęciowej zaprezentowanej w pierwszym tomie Wallersteina. Jak określił Swianiewicz, Wallerstein wręcz ,spadł z nieba” Braudelowi, który oparł swoją niedopracowaną dotąd terminologię na kategoriach opracowanych przez Amerykanina ${ }^{54}$. Zwróćmy w zarysie uwagę na główne różnice w podejściach obu autorów.

Dla Fernanda Braudela kapitalizm był najwyższym piętrem gospodarki -świata i pojawił się po przekroczeniu progu gospodarki naturalnej, nakierowanej na zaspokojenie własnych potrzeb. W tym rozumieniu kapitalizm jest rzadkim fenomenem historycznym, który opiera się na koncentracji i pomnażaniu kapitału. Kapitaliści to po prostu międzynarodowa elita finansowa i kupiecka ${ }^{55}$. Zdaniem Francuza kapitalizm jest możliwy w każdej dziedzinie gospodarki, ponieważ kapitaliści dążą do zysku niezależnie od rodzaju prowadzonej działalności. W Europie system ten oparł się w XIII wieku na kupcach włoskich, którzy zdominowali handel śródziemnomorski. Bazą dla tej działalności była rosnąca zamożność miast począwszy od końca XI wieku, czyli początków wypraw krzyżowych ${ }^{56}$.

Dla Braudela oczywiste było równoczesne istnienie różnych systemów gospodarczych w Europie, Afryce, czy Azji, przyjmował odrębną perspektywę dla różnych kontynentów. Ujęcie takie było konsekwencją analizy wielopoziomowej. Gospodarka-świat jest dla Braudela wyodrębniona dzięki geografii ekonomicznej.

${ }^{54}$ A. Sosnowska, Zrozumieć zacofanie..., rozdział 1; J. Swianiewicz, Możliwość makrohistorii..., rozdziały 10-11, s. 311-366.

${ }_{55}$ F. Braudel, Kultura materialna ..., t. 2, s. 5-8.

${ }^{56}$ F. Braudel, Kultura materialna ..., t. 3, s. 63-64, 76-79. 
Dla socjologa rozwoju Wallersteina podział na centrum, półperyferie i peryferie wynika raczej z koncentracji nadwyżki ekonomicznej w ręku kapitalistów, co powoduje odmienną trajektorię rozwoju miejsc, w których zainwestowany zostanie kapitał.

Wallerstein rozumie pojęcie kapitalizmu dużo prościej, ale też o wiele szerzej niż Braudel. Dla niego kapitalistą jest w zasadzie każdy, kto dąży do akumulacji kapitału. Różnica uwidacznia się w pojmowaniu przez dwóch badaczy sytuacji Europy Wschodniej, która zdaje się szczególnie interesująca dla polskiego czytelnika. Zdaniem Wallersteina, polska szlachta w XVI-XVIII wieku to już de facto kapitaliści produkujący na rynek europejski (który zaistniał obok rynku krajowego) i zyskujący dzięki temu systemowi pozycję na rynku krajowym. Właściciele folwarków, którzy maksymalizowali zyski z handlu zbożem rzeczywiście szybko zdobyli dominację polityczną $\mathrm{w} \mathrm{kraju}^{57}$. $\mathrm{Z}$ powodu tejże dominacji Polska stała się zakładnikiem szlachty i surowcowym zapleczem Europy Zachodniej oraz pierwszą peryferią - i ofiarą - powstającego kapitalistycznego systemu-świata ${ }^{58}$.

Braudel uważał inaczej i powoływał się na badania Witolda Kuli, zawarte w Teorii ekonomicznej ustroju feudalnego. Szlachta polska produkowała wprawdzie zboże na rynek Europy Zachodniej, ale dostęp na ten rynek kontrolowany był przez rezydujących w Gdańsku pośredników - kupców niderlandzkich ${ }^{59}$. Współpraca z kapitalistami nie czyniła z polskiej szlachty kapitalistów, ale dostawców. Dla Wallersteina już samo pełnienie jakiejkolwiek roli (zwłaszcza producenta!) w systemie kapitalistycznym tworzy ów system. Amerykanin powołał się na ustalenia innego polskiego badacza - Mariana Małowista wskazując, że to właśnie handel decydował o kierunku produkcji i podziale dochodu społecznego w Europie Wschodniej ${ }^{60}$. Uzależnienie polskiej produkcji od handlu i zachodnich kupców nie poprzedzało kapitalizmu, ale właśnie było związane z kapitalizmem par excellence $e^{61}$. Wallerstein uważał, że nieistotne są wewnętrzne analogie ustroju feudalnego Polski średniowiecznej i nowożytnej. Dla niego decydującym faktem nie była racjonalność gospodarowania przez polską szlachtę nadwyżką ekonomiczną, ale to, że produkowała ona na rynek globalny ${ }^{62}$. To właśnie zdecydowało

57 Proces rosnacej dominacji politycznej szlachty ciekawie, choć nieco tendencyjnie przedstawił J. Sowa, Fantomowe ciało króla. Peryferyjne zmagania z nowoczesna forma, Kraków 2011.

58 Por. A. Sosnowska, Zrozumieć zacofanie..., s. 47-48, J. Topolski, Narodziny kapitalizmu..., Posłowie, s. 183-185.

59 W. Kula, Teoria ekonomiczna..., s. 39-86; F. Braudel, Kultura materialna ..., t. 2, s. $241-246$.

${ }^{60}$ M. Małowist, Problem nierówności rozwoju gospodarczego w Europie w późnym średniowieczu, [w:] tenże, Europa i jej ekspansja XIV-XVII w., Warszawa 1993, s. 14-28. Tekst to zapis wykładu wygłoszonego w All Souls College w Oksfordzie 8 maja 1965, publikacja oryginalna w języku angielskim na łamach The Economic History Review, II, 19, 1966, s. 15-28.

${ }^{61}$ Ibidem, s. 28; A. Sosnowska, Zrozumieć..., s. 110-111, 210-211.

${ }^{62}$ Por. W. Kula, Zacofanie gospodarcze w perspektywie historycznej, [w:] tenże, Historia, zacofanie, rozwój, Warszawa 1983, s. 187-192 (tekst po raz pierwszy ukazał się po włosku w 1969 roku, a więc na kilka lat przed ogłoszeniem tez Wallersteina); M. Starnawski, P. Wielgosz, (Przed- 
o reprodukcji systemu gospodarczego, struktury społecznej i układu sił w polityce międzynarodowej na kilka stuleci. Dla Braudela kapitalizm był zajęciem nielicznych osób - kapitalistów, wykorzystujących nierówności i różnice cen dla wzbogacenia się. Dla Wallersteina kapitalizm stał się nazwą całego systemu. Związany był ściśle z rozwojem masowej gospodarki towarowo-pieniężnej w Europie Zachodniej, która okazała się podstawą ekspansji politycznej i gospodarczej zachodnich Europejczyków.

Rozpatrując kolejne kwestie, Braudel uważał, że fundamentem gospodarki jest kultura materialna (metody uzyskiwania energii, dóbr i konsumpcja) i wymiana rynkowa (zwykle miasto-wieś). Kapitalizm był tylko nadbudową. Wallerstein zaś odwrotnie, przyjmował, że fundamentem począwszy od XVI wieku jest właśnie kapitalizm, wiążący nićmi handlu wszystkie stopniowo obszary na świecie. Kapitalizm rozumiany jest tu zgodnie z regułami ekonomii politycznej jako zestaw zasad systemowych, umożliwiających Zachodowi polityczny podbój i peryferyzację innych kontynentów (o ile państwa wspierały instytucje handlowe ${ }^{63}$. Polski uczony Witold Kula m. in. na łamach Annales jeszcze w latach 60. XX wieku wskazywał, że geneza kapitalizmu oraz jego funkcjonowanie w gospodarce industrialnej będą kluczowymi zagadnieniami historii ekonomicznej XX wieku ${ }^{64}$.

Punkty wspólne dla ujęcia Braudela i Wallersteina próbował przedstawić Jerzy Topolski, który w posłowiu do włoskiego wydania własnej pracy Narodziny kapitalizmu w Europie XIV-XVII wieku zbliżył się do obu stanowisk. Jego zdaniem Wallerstein przeceniał znaczenie wymiany ekonomicznej, gdyż decydujące zmiany w Europie Wschodniej miały charakter polityczny. Z drugiej jednak strony przyznawał, że rozwój miast i gospodarki towarowo-pieniężnej zaktywizował szlachtę w stronę akumulacji kapitału i doprowadził do zastępowania feudalizmu kapitalizmem w Europie Zachodniej. Szlachta rywalizując z mieszczaństwem również zajęła się produkcją, inwestycjami i wykazała się aktywnością w podbojach kolonialnych (zwłaszcza szlachta iberyjska, o czy pisał Małowist). Rozejście się dróg Europy Zachodniej i Wschodniej stało się jednak faktem dopiero w XVII wieku w wyniku słabości miast i refeudalizacji części wschodniej ${ }^{65}$.

Koncepcja gospodarki-świata rozumiana jest na także dwa różne sposoby. Braudel jako historyk wybierał przestrzenne uwarunkowania procesów gospodarczych jako podstawę badania gospodarki-świata. Tym samym według jego wizji w samej Europie począwszy od XIII wieku istniało kilka różnych gospodarek z różnymi centrami (Wenecja, Amsterdam, Londyn). Podobnie było na innych konty-

mowa do wydania polskiego) Kapitalizm nad przepaścia, społeczeństwa wobec wyboru, [w:] I. Wallerstein, Analiza systemów-światów. Wprowadzenie, Warszawa 2007, s. XXIV-XXIX.

${ }^{63}$ Piszę o tym w: T. Pawłuszko, Kategoria systemu międzynarodowego w badaniu stosunków międzynarodowych, Toruń 2014, s. 140-145.

${ }^{64}$ W. Kula, Historia i ekonomia: dtugie trwanie, [w:] tenże, Historia, zacofanie rozwój..., s. 236-255. Tekst był odpowiedzią polskiego historyka na manifest F. Braudela, opublikowaną pierwotnie w Annales w 1960 roku.

${ }^{65}$ J. Topolski, Narodziny kapitalizmu..., s. 183-185. 
nentach. Ich analizie poświęcił trzeci tom Kultury materialnej ${ }^{66}$. Tymczasem Wallerstein uznał kapitalizm za uniwersalną zasadę realnych procesów historycznych, które miały miejsce począwszy od XVI wieku i spowodowały ekspansję zamorską Portugalii, Hiszpanii i Holandii, do których szybko dołączyły Anglia i Francja ${ }^{67}$. Podboje Europejczyków nie wynikały z biedy, strachu, ani zacofania. Wiązały się ściśle ze zdobywaniem pozycji na rynkach w światowym handlu ${ }^{68}$. Władze polityczne ochoczo wsparły ekspansję szlachty i kupiectwa, powołując rządowe kompanie handlowe, wspierając militarnie, zajmując terytoria i tworząc kolonie. W tym miejscu Braudel i Wallerstein zgadzali się ze sobą; kapitalizm nie dąży do wolnego rynku, ale do monopolu ${ }^{69}$. Wizja Braudela wiązała się jednak ze światem nowożytnym, dla Wallersteina punktem orientacyjnym był XX wiek i jego podział na centra, półperyferie i peryferie (tu zauważalna inspiracja teorią dependystów). Braudelowi zarzucić można nadmierny historyzm, a Wallersteinowi prezentyzm.

Tabela 1. Typologia badań rozwoju gospodarki-świata według F. Braudela w długim trwaniu

\begin{tabular}{|c|c|c|c|c|}
\hline & Wzrost & Kryzys & Spadek & Liczba obszarów badań \\
\hline Centrum & $\begin{array}{l}\text { 1. gospodarka, } \\
\text { 2. polityka, } \\
\text { 3. kultura, } \\
\text { 4. hierarchia } \\
\text { społeczna. }\end{array}$ & $\begin{array}{l}\text { 5. gospodarka, } \\
\text { 6. polityka, } \\
\text { 7. kultura, } \\
\text { 8. hierarchia } \\
\text { społeczna. }\end{array}$ & $\begin{array}{l}\text { 9. gospodarka, } \\
\text { 10. polityka, } \\
\text { 11. kultura, } \\
\text { 12. hierarchia } \\
\text { społeczna. }\end{array}$ & 12 \\
\hline $\begin{array}{l}\text { Pół } \\
\text { peryferie }\end{array}$ & $\begin{array}{l}\text { 13. gospodarka, } \\
\text { 14. polityka, } \\
\text { 15. kultura, } \\
\text { 16. hierarchia } \\
\text { społeczna. }\end{array}$ & $\begin{array}{l}\text { 17. gospodarka, } \\
\text { 18. polityka, } \\
\text { 19. kultura, } \\
\text { 20. hierarchia } \\
\text { społeczna. }\end{array}$ & $\begin{array}{l}\text { 21. gospodarka, } \\
\text { 22. polityka, } \\
\text { 23. kultura, } \\
\text { 24. hierarchia } \\
\text { społeczna. }\end{array}$ & 12 \\
\hline Peryferie & $\begin{array}{l}\text { 25. gospodarka, } \\
\text { 26. polityka, } \\
\text { 27. kultura, } \\
\text { 28. hierarchia } \\
\text { społeczna. }\end{array}$ & $\begin{array}{l}\text { 29. gospodarka, } \\
\text { 30. polityka, } \\
\text { 31. kultura, } \\
\text { 32. hierarchia } \\
\text { społeczna. }\end{array}$ & $\begin{array}{l}\text { 33. gospodarka, } \\
\text { 34. polityka, } \\
\text { 35. kultura, } \\
\text { 36. hierarchia } \\
\text { społeczna. }\end{array}$ & 12 \\
\hline RAZEM & & & & 36 \\
\hline
\end{tabular}

Źródło: opracowanie własne na podstawie F. Braudel, Kultura materialna, gospodarka i kapitalizm XV-XVIII wiek. Tom 3 - Czas świata, Warszawa 1992, s. 70-71.

Powyższy wykres jest próbą Fernanda Braudela stworzenia koncyliacyjnej mapy zagadnień dla badania systemu gospodarki-świata. Francuz korzystając z koncepcji Wallersteina centrum-peryferie, a także własnej konceptualizacji kwestii rozwoju, kryzysu i spadku pragnął stworzyć uniwersalny model badania rozwoju, kryzysu i upadku poszczególnych elementów systemów gospodarki

${ }^{66}$ F. Braudel, Kultura materialna ..., t. 3, rozdziały 3-7.

${ }^{67}$ I. Wallerstein, Koniec świata..., s. 17-20.

${ }^{68}$ Ibidem, s. 15-18.

${ }^{69}$ Por. Amerykanin podkreśla to wielokrotnie I. Wallerstein, Analiza systemów-światów..., s. 44-49. Por. P. Baran, P. Sweezy, Kapitat monopolistyczny. Szkice o amerykańskim systemie gospodarczym i spotecznym, Warszawa 1968. 
-świata. Model ten nie pretenduje do roli ścisłego, ani matematycznego. Nie posiada schematów wyjaśniających, ani wskaźników. Posiada jednak sporą wartość poznawczą. Dalszy rozwój koncepcji gospodarki-świata i analizy na jej bazie mógłby dostarczyć danych dla jego wypełnienia. F. Braudel zdawał sobie sprawę, że badanie zmian społecznych w skali globalnej jest karkołomnym przedsięwzięciem. I. Wallerstein zdobył się na uproszczenie w swojej teorii wysuwając czynnik ekonomiczny (według logiki kapitalizmu) jako decydujący dla kształtowania się międzynarodowego podziału pracy.

W kontekście wykresu warto jednak zwrócić uwagę, że dla Braudela świat stanowi kilka systemów-światów, powiązanych kulturowo, przestrzennie i materialnie (dziś, w epoce Internetu, nie jest to wcale uproszczenie). Dla Wallersteina system gospodarki-świata istnieje jeden (choć uznawał istnienie kilku gospodarek-światów w czasach przednowożytnych). Sposobów jego wyjaśniania jest tak dużo, że badacze ze szkoły Wallersteina nie zdecydowali się nazwać swego podejścia teorią. Wspomniane już współczesne kompendium Handbook of World -Systems Analysis wydane w 2012 roku przez wydawnictwo Routledge liczy kilkadziesiąt tematów badawczych, a poprzez stałą działalność sekcji Political Economy of the World-System w ramach American Sociological Association, dochodzą kolejne zagadnienia.

Kolejnym punktem zbieżności obu koncepcji były próby periodyzacji zmian społeczno-gospodarczych w makro-skali. Braudel i Wallerstein okresowo przyjęli podobne ujęcie cykli rozwoju gospodarczego. Były to próby synchronizacji koncepcji cykli Juglara (3-4 lata), Kuznetsa (20-25 lat) i Kondratiewa (50 lat ${ }^{70}$. Braudel wnosił swoje podejście na bazie badań cen, Wallerstein na bazie zużycia środków trwałych i innowacjach. Dla obu punktem odniesienia były pisma Josepha Schumpetera, poświęcone rozwojowi ekonomicznemu ${ }^{71}$. Najdłuższym trendem miał być właściwy koncepcji długiego trwania trend sekularny (100-150 lat). Braudel pisał: „Moim zdaniem wibracje o wiekowym trwaniu, nie dające się wyjaśnić bez wprowadzenia ogromnej i ograniczonej zarazem przestrzeni gospodarki świata, pulsują nieustannie, wywierając zmienny wpływ na złożone prądy koniunktury" "72.

Obaj autorzy nie traktowali jednak „twardej” periodyzacji jako warunku koniecznego dla obowiązywania swoich wizji. Braudel pisał, że na podstawie informacji o kryzysie naftowym lat 70. XX wieku można wnioskować, że około 2000 roku wystąpi kryzys gospodarki-świata: „Skłaniam się ku temu sądowi, chociaż brak mi dowodów. A jeśli książka ta wpadnie pewnego dnia w ręce czytelnika żyjącego po roku 2000, to - być może - rozbawi go tych kilka wierszy, tak jak mnie, w stanie trochę nieczystego sumienia, rozbawiło jakieś głupstwo,

${ }^{70}$ I. Wallerstein, Koniec świata ..., s. 15-17; F. Braudel, Kultura materialna ..., t. 3, s. 58-71.

${ }_{71}$ J. Schumpeter, Teoria rozwoju gospodarczego, Warszawa 1960.

${ }^{72}$ F. Braudel, Kultura materialna..., t. 3, s. 67. 
które wymknęło się spod pióra Jeana Baptiste Saya"73. Wallerstein również podtrzymywał aktualność koncepcji cykli Kondratiewa jeszcze w książkach z 1999 i 2004 roku (w 2005 roku otrzymał złoty medal Międzynarodowej Fundacji im. N. Kondratiewa), ale w późniejszych pismach stopniowo odszedł od ścisłego rozumienia cykliczności rozwoju gospodarczego.

\section{PRÓBA PODSUMOWANIA}

Znaczenie omówionych kwestii dla badania stosunków międzynarodowych jest bardzo ważne. Historia społeczna i gospodarcza jest wiedzą niezbędną z perspektywy diagnozy stanu każdego systemu międzynarodowego, zwłaszcza w okresie kryzysu i chaosu informacyjnego. Nauki społeczne bardziej niż kiedykolwiek potrzebują twórczej pracy nad teoriami umożliwiającymi zdobycie rzetelnej wiedzy o zmiennej rzeczywistości. Dane historyczne umożliwiają pogłębienie analizy, a hierarchizacja jakości instytucji politycznych i gospodarczych według schematu centrum-peryferie ułatwia badania porównawcze.

Nawet wstępne porównanie prac uczonych o tak wpływowym dorobku jak Fernand Braudel i Immanuel Wallerstein jest bardzo trudne i wymaga wielojęzycznych lektur dotyczących metodologii, historii gospodarczej, socjologii rozwoju, międzynarodowej ekonomii politycznej, historii instytucji politycznych, historii kapitalizmu i wielu innych. Ważne są tu zarówno korzenie refleksji obu myślicieli i ich szkół, refleksja ich jako taka, a także krytyka na przestrzeni dekad. Trud ten będzie kontynuowany, ponieważ przekracza rozmiary pojedynczego szkicu. Autorskie podsumowanie obecnej refleksji przedstawiam w tabeli $\mathrm{nr} 2$.

Tabela wskazuje, że obie koncepcje pomimo różnic są sobie zasadniczo bliskie. Posiadają podobne korzenie intelektualne. Po pierwsze, odwołują się do potrzeby integracji nauk społecznych, po drugie akceptują wielość metod badawczych, po trzecie wskazują na duże znaczenie przeszłości w badaniu warunków teraźniejszości, po czwarte podkreślają znaczenie elit i nierówności społecznych, po piąte odwołują się bezpośrednio do zagadnienia rozwoju Europy Środkowo -Wschodniej. Po szóste, wymagają interdyscyplinarnej refleksji. Wszystko to tworzy fascynujące pole eksploracji naukowej o nadal dużym znaczeniu praktycznym i edukacyjnym.

Wszystkie wspomniane powyżej kwestie pozostają ważne zwłaszcza w kontekście pozycji Europy Środkowo-Wschodniej w systemie międzynarodowym. Próby przezwyciężenia długofalowego zapóźnienia względem najbogatszych państw świata wygenerowały w XX wieku liczne koncepcje rozwoju społeczno-gospodarczego. Wiek XXI nie będzie w tym temacie inny. Świadczą o tym dyskusje specjalistyczne na temat kondycji kapitalizmu, globalizacji, liberalizmu, integracji gospodarczej i inne. Nie można ich nie podjąć, zwłaszcza że na polskim

73 Ibidem, s. 69. 
Tabela 2. Porównanie koncepcji systemu-świata F. Braudela i I. Wallersteina

\begin{tabular}{|c|c|c|}
\hline & Fernand Braudel & Immanuel Wallerstein \\
\hline Dyscyplina wiodąca & Historia & Socjologia \\
\hline Wizja nauki & Historia totalna & Historyczne nauki społeczne \\
\hline Podejście do historii & $\begin{array}{c}\text { Historia jako główna dyscyplina } \\
\text { ogólna, zwłaszcza w ujęciu } \\
\text { geograficznym }\end{array}$ & $\begin{array}{l}\text { Łączenie historii z naukami } \\
\text { społecznymi (socjologia, } \\
\text { politologia, ekonomia), podstawą } \\
\text { socjologia }\end{array}$ \\
\hline Inspiracje & $\begin{array}{c}\text { K. Marks, W. Sombart, M. } \\
\text { Bloch, L. Febrve, J. Schumpeter, } \\
\text { K. Polanyi, W. Kula, } \\
\text { I. Wallerstein, M. Foucault }\end{array}$ & $\begin{array}{l}\text { K. Marks, F. Fanon, F. Braudel, } \\
\text { I Prigogine, K. Polanyi, } \\
\text { J. Schumpeter, R. Prebisch, } \\
\text { A.G. Frank, M. Małowist }\end{array}$ \\
\hline Kapitalizm & $\begin{array}{c}\text { Koncentracja i pomnażanie } \\
\text { kapitału przez zamożne elity }\end{array}$ & $\begin{array}{c}\text { Akumulacja kapitału i udział } \\
\text { międzynarodowym podziale pracy }\end{array}$ \\
\hline Kapitaliści & $\begin{array}{c}\text { Wąska międzynarodowa elita } \\
\text { kupiecka i finansowa }\end{array}$ & $\begin{array}{l}\text { Kupcy i producenci akumulujący } \\
\text { kapitał }\end{array}$ \\
\hline Poziomy analizy & $\begin{array}{c}\text { mikrohistoria, } \\
\text { historia koniunkturalna, } \\
\text { historia strukturalna }\end{array}$ & $\begin{array}{c}\text { Minisystemy } \\
\text { Imperia-światy } \\
\text { Gospodarki-światy } \\
\end{array}$ \\
\hline Gospodarka-świat & $\begin{array}{l}\text { Fragment gospodarki światowej } \\
\text { o odrębnej specyfice }\end{array}$ & $\begin{array}{c}\text { Kapitalistyczny system } \\
\text { gospodarowania tworzący globalny } \\
\text { podział produkcji }\end{array}$ \\
\hline $\begin{array}{l}\text { Geneza gospodarki } \\
\text {-świata }\end{array}$ & XIII wiek (Europa) & XVI wiek (Europa) \\
\hline $\begin{array}{l}\text { Struktura gospodar- } \\
\text { ki-świata }\end{array}$ & $\begin{array}{l}\text { Centra, półperyferie, peryferie, } \\
\text { tereny neutralne }\end{array}$ & $\begin{array}{c}\text { Centra, półperyferie, peryferie, } \\
\text { obszary zewnętrzne }\end{array}$ \\
\hline $\begin{array}{l}\text { Relacje w ramach } \\
\text { struktury gospodarki } \\
\text {-świata }\end{array}$ & $\begin{array}{l}\text { Obszary centrum są zależne od } \\
\text { obszarów zacofanych }\end{array}$ & $\begin{array}{l}\text { Obszar centrum wyzyskuje } \\
\text { peryferia i półperyferia. }\end{array}$ \\
\hline $\begin{array}{c}\text { Zmienność } \\
\text { gospodarki-świata }\end{array}$ & $\begin{array}{l}\text { Zmiany wynikają z rozwoju lub } \\
\text { upadku centrów gospodarczych } \\
\text { (gł. miast) }\end{array}$ & $\begin{array}{l}\text { Obszar centrów jest zależny od } \\
\text { interesów kapitalizmu, akces } \\
\text { do centrum możliwy poprzez } \\
\text { zaproszenie, okazję lub autarkię, } \\
\text { możliwy spadek do statusu } \\
\text { półperyferii lub peryferii. }\end{array}$ \\
\hline $\begin{array}{l}\text { Trendy gospodarki- } \\
\text { świata }\end{array}$ & $\begin{array}{l}\text { Trendy Juglara, Kuznetsa, Cykle } \\
\text { Kondratiewa, trendy sekularne }\end{array}$ & $\begin{array}{l}\text { Trendy Kuznetsa, Cykle } \\
\text { Kondratiewa, trendy sekularne } \\
\text { (tzw. cykle logistyczne) }\end{array}$ \\
\hline
\end{tabular}

Źródło: opracowanie własne

gruncie są dobre warunki do ich analizy. Być może studia nad rozwojem i transformacją społeczno-ekonomiczną mogłyby być jedną z polskich specjalizacji w naukach społecznych. 
Title: Fernand Braudel's Approach to World-Economy Analysis.

Summary: This article outlines the concept of the global economic system according to Fernand Braudel. This topic is related to the almost simultaneously formulated theory of the world-system by Immanuel Wallerstein, but remains almost unknown in the current literature. The author intends to examine the conceptual categories and theoretical themes developed by of the French historian to examine their application in contemporary analysis of international relations. Braudel's concept refers to the theory of economic history, the periphery-center theory, and the study of capitalism and political power. The selection of this theme is linked to broader work on the determinants of the position of the European region in the world economy.

Keywords: Fernand Braudel, system-world, Immanuel Wallerstein, centers and periphery, Annales

\section{BIBLIOGRAFIA}

1. ALEKSY A., 2005: Teoria systemu światowego Immanuela Wallersteina oraz jej znaczenie dla teorii stosunków międzynarodowych. W: Porządek międzynarodowy u progu XXI wieku, R. Kuźniar (red.), Warszawa.

2. BABONES S.J., CHASE-DUNN Ch. (red.), 2012: Routledge Handbook of World-Systems Analysis, London \& New York.

3. BARAN P., SWEEZY P., 1968: Kapitał monopolistyczny. Szkice o amerykańskim systemie gospodarczym i spolecznym, Warszawa.

4. BERGER P., T. LUCKMANN, 1983: Spoleczne tworzenie rzeczywistości, Warszawa.

5. BLOCH M., 2009: Pochwata historii, czyli o zawodzie historyka, Kęty.

6. BRAUDEL F., 1976-1977: Morze Śródziemne i świat sródziemnomorski w epoce Filipa II, t.1-2, Gdańsk.

7. BRAUDEL F., 1992: Kultura materialna, gospodarka i kapitalizm XV-XVII wiek, t.1-3, Warszawa.

8. BRAUDEL F., 1999: Historia i trwanie, Warszawa.

9. BUZAN B, LITTLE R., 2011: Systemy międzynarodowe w historii świata, Warszawa.

10. CZAPUTOWICZ J., 2006: Teorie stosunków międzynarodowych. Krytyka i systematyzacja, Warszawa.

11. CZAPUTOWICZ J., ŁAWNICZAK K., WOJCIUK A., 2015: Nauka o stosunkach międzynarodowych $i$ studia europejskie $w$ Polsce, Warszawa.

12. FRANK, A.G., 2000: Immanuel and Me With-Out Hyphen. "Journal of World-Systems Research", vol. 6, no. 2, s. 216-231.

13. FUKUYAMA F., 2012: Historia ładu politycznego, Od czasów przedludzkich do rewolucji francuskiej, Poznań.

14. GAŁGANEK A., 1992: Zmiana w systemie międzynarodowym. Supercykle $i$ wojna hegemoniczna, Poznań.

15. GAŁGANEK A., 2013: Historia stosunków międzynarodowych. Nierówny i połaczony rozwój, t.1-2, Warszawa.

16. GOLDFRANK W., 2000: Paradygmat odzyskany? System-świat I. Wallersteina i jego analiza, dostępny on-line: http://www.turowski.uni.wroc.pl/paradygmat.htm (26.03.2017).

17. HICKS J., 2000: Teoria historii gospodarczej, Torun.

18. HOPKINS T.K., WALLERSTEIN I. et al., 1982: World-Systems Analysis: Theory and Methodology, Beverly Hills. 
19. HRYNIEWICZ J., 2010: Teoria centrum-peryferie w epoce globalizacji. „Studia Regionalne i Lokalne", nr 2 (40), s. 5-27;

20. HRYNIEWICZ J., 2013: Centrum-Peryferie. Stara teoria w nowych czasach. „Studia Polityczne", nr 31, s. 291-313.

21. ILKOWSKI F., 2015: Imperializm kapitalistyczny we wspótczesnych ujęciach teoretycznych, Toruń.

22. INGHAM G., 2009: Kapitalizm, Warszawa.

23. KLEMENTEWICZ T., 2012: Teorie stosunków międzynarodowych $w$ strukturze wiedzy humanistycznej o systemie światowym (cywilizacji światowej). W: Wielo- i interdyscyplinarność nauki o stosunkach międzynarodowych, A. Gałganek, E. Haliżak, M. Pietraś (red.), Warszawa, s. $400-406$.

24. KLEMENTEWICZ T., 2013: Geopolityka trwałego rozwoju, Warszawa.

25. KLEMENTEWICZ T., 2015: Stawka większa niż rynek. U źródeł kapitalizmu bez granic, Warszawa.

26. KOCHANOWICZ J., 2006: Backwardness and Modernization. Poland and Eastern Europe in the 16th-20th Centuries, Burlington.

27. KOCHANOWICZ J., 1992: Twórca i dzieło. W: F. Braudel, Kultura materialna, gospodarka i kapitalizm XV-XVIII wiek, t. 1, Warszawa, s. 5-7.

28. KULA W., 1983: Historia. Zacofanie. Rozwój, Warszawa.

29. KULA W., 1983: Teoria ekonomiczna ustroju feudalnego, II wyd., Warszawa.

30. KULA W., 1993: Rozwój gospodarczy Polski XVI-XVIII w., Warszawa.

31. KULA W., 2009: Przedmowa. W: M. Bloch, Pochwata historii, czyli o zawodzie historyka, Kęty, s. 15-28.

32. KULA W., GEREMEK B., 1999: Przedmowa. W: F. Braudel, Historia i trwanie, Warszawa, s. $6-8$.

33. KULISZER J., 1961: Powszechna historia gospodarcza średniowiecza i czasów nowożytnych, Warszawa.

34. MAŁOWIST M., 1966: The Problem of the Inequality of Economic Development in Europe in the Later Middle Ages. "The Economic History Review", vol. 19, no 1. s. 15-28.

35. MAŁOWIST M., 1993: Europa i jej ekspansja XIV-XVII w., Warszawa.

36. MAŁOWIST M., 2006: Wschód a Zachód Europy w XIII-XVI wieku. Konfrontacja struktur społeczno-gospodarczych, Warszawa.

37. NORTH D., 2014: Zrozumieć przemiany gospodarcze, Warszawa.

38. PASZTOR M., 2006: Francja wobec października 1956 r. w Polsce. W: Polski październik 1956 w polityce światowej, J. Rowiński (red.), Warszawa 2006, s. 263-276.

39. PAWŁUSZKO T., 2014: Kategoria systemu międzynarodowego w badaniu stosunków międzynarodowych, Torun.

40. POLANYI K., 2010: Wielka transformacja. Polityczne i ekonomiczne źródła naszych czasów, Warszawa.

41. PREBISCH R., 1959: Commercial Policy in the Underdeveloped Countries, "American Sociological Review", vol. 49, no. 2, s. 251-273.

42. REWIZORSKI M.,2009: Koncepcja systemu światowego wedtug Immanuela Wallersteina, „Przegląd Politologiczny”, nr 1, s. 65-78.

43. SCHUMPETER J., 1954: History of Economic Analysis, London.

44. SCHUMPETER J., 1995: Kapitalizm, socjalizm, demokracja, Warszawa. 
45. SKARZYŃSKI R., 2012: Podstawowy dylemat politologii, Białystok.

46. SOMBART W., 1928: Der Moderne Kapitalismus, wyd. 15, Berlin.

47. SOSNOWSKA A., 2004: Zrozumieć zacofanie. Spory historyków o Europę Wschodnia 19471994, Warszawa.

48. SOWA J., 2011: Fantomowe ciało króla. Peryferyjne zmagania z nowoczesna forma, Kraków.

49. STARNAWSKI M., Wielgosz P., 2007: (Przedmowa do wydania polskiego) Kapitalizm nad przepaścia, spoteczeństwa wobec wyboru. W: I. Wallerstein, Analiza systemów-światów. Wprowadzenie, Warszawa.

50. SWIANIEWICZ J., 2014: Możliwość makrohistorii. Braudel. Wallerstein. Deleuze, ToruńWarszawa.

51. TOPOLSKI J., 2003: Narodziny kapitalizmu w Europie XIV-XVII wieku, Poznań.

52. WALLERSTEIN I., 1974: The Modern World-System: Capitalist Agriculture and the Origins of the European World-Economy in the Sixteenth Century, New York.

53. WALLERSTEIN I., 1974: The Rise and Future Demise of the World Capitalist System: Concepts for Comparative Analysis. "Comparative Studies in Society and History", no. 16, s. 387-415.

54. WALLERSTEIN I., 1979: The Capitalist World-Economy, Cambridge.

55. WALLERSTEIN I., 1983: Historical Capitalism, London.

56. WALLERSTEIN I., 1984: Politics of the World-Economy, Cambridge.

57. WALLERSTEIN I., 1991: Geopolitics and Geoculture, Cambridge.

58. WALLERSTEIN I., 1991:Unthinking Social Science: The Limits of Nineteenth Century Paradigms, Cambridge.

59. WALLERSTEIN I., 1995: After Liberalism, New York.

60. WALLERSTEIN I., 2004: Koniec świata jaki znamy, Warszawa.

61. WALLERSTEIN I., 2007: Analiza gospodarki-świata. Wprowadzenie, Warszawa.

62. ZARYCKI T. (red.) 2016: Polska jako peryferie, Warszawa.

63. ZIEWIEC G., 2009: Wallersteina i Fukuyamy prognozy systemu kapitalistycznego, „Gospodarka Narodowa", nr 1-2, s. 27-47. 